\title{
Profile Characteristics of Agricultural Input Dealers in West Bengal
}

\author{
Amitava Panja ${ }^{1}$, N. S. Shivalinge Gowda ${ }^{2}$, D. V. Kusumalatha ${ }^{2}$ \\ and N. Mamathalakshmi ${ }^{3}$ \\ ${ }^{1}$ Department of Dairy Extension, National Dairy Research Institute, Karnal, Haryana, India \\ ${ }^{2}$ Department of Agricultural Extension, UAS, GKVK, Bengaluru, Karnataka, India \\ ${ }^{3}$ Department of Horticulture, Mysuru, Karnataka, India \\ *Corresponding author
}

\section{A B S T R A C T}

The profile characteristics of agricultural input dealers of Purba Bardhaman and Hooghly districts of West Bengal were measured for the study. Eighty agricultural input dealers; forty from each district were selected using random

Keywords

Agricultural input dealers, Profile characteristics, West Bengal

Article Info

\section{Accepted:}

17 January 2021

Available Online:

10 February 2021 sampling method and were interviewed for the study. Ex-post facto research design was used for the study. Respondents were personally interviewed with the help of a pre-tested questionnaire. Distribution of the respondents based on personal, socio-economic, psychological and extension characteristics showed that majority of the agricultural input dealers were middle aged $(61.25 \%)$, had formal education till graduation (31.25\%), medium annual income $(62.50 \%)$, medium cosmopoliteness (53.75\%), medium self-confidence (37.50\%), medium deferred gratification $(51.25 \%)$, medium competition orientation (45.00\%), high credit orientation (48.75\%), medium level of aspiration (40.00\%), medium empathy $(56.25 \%)$, medium information sharing behaviour (50.00\%), medium extension contact (55.00\%), medium extension participation $(53.75 \%)$, medium social participation $(38.75 \%)$ and medium mass media participation $(52.50 \%)$.

\section{Introduction}

Agriculture is the major dominating occupation catering to the employment of huge segment of population worldwide. In India, almost 60 per cent of the workforce relies upon agriculture as their primary occupation and contributes almost 16.50 per cent of India's GVA. The nation has witnessed a record food grain production (296.65 million tonnes) despite of the unfavourable situations prevailed due to Covid-19 and there is also an estimation of 301 million tonnes production of food grains in 2020-21 (PIB, 2020). This sector contributes almost $16.50 \%$ of India's GVA and has estimated a record production of 
291.95 million tonnes food grains in 2019-20 (Anon., 2020). In order to continue with this sustaining growth of agriculture in India and to achieve the targeted value, multi-prolonged strategy, including effective and efficient delivery of farm information, is a prerequisite. However, the ratio of extension service provider to operational farm holdings has also reduced far below against a recommended rate of 1:750 (Nandi, 2019).

Indian agriculture is characterized by the presence of small and marginal farmers, with fragmented land holdings and they are lagging behind in terms of resource and knowledge base. There are almost 138 million operational agricultural holdings in India, of which around 85 per cent are small and marginal farmers (Census 2010-11). They often lack awareness of various agro-advisory services like training of new farm technologies, diagnosis of pests and disease infestations in different crop and correct types and dosage of particular agro-chemicals to treat them. Numerous incidents take place of inappropriate use of agro-chemicals resulting in loss of yield, loss of standing crop and many consequences, which are grave and fatal to the farming community. Insufficient availability of information and inappropriate farming practices also ends up with destruction of natural resources, which are irreversible e.g. soil fertility.

True development of the farmers is only possible if the system of agricultural extension is able to meet the relevant and significant needs and interests of the clients; and this can happen if both public and private extension can act as complement and supplement to each other, and behave as a single unit of information dissemination and technology transfer. In this scenario, agricultural input dealers become a prime source of extension advisory services, clearly having a location advantage, good rapport and easy accessibility by the farmers. Availability of agricultural inputs, quality of the product, and availability of preferred brand increases loyalty of the agricultural input dealers among the farmers (Padmanabhan, 1999). Thus, agricultural input dealer bears the responsibility to spread the latest farm technology up to the field level, especially in the era of free economy and world trade organisation (Khose, 2004).Commercial farming, besides having a requirement of high investment and technology, also needs timely supply of all types of agricultural inputs including agroadvisory services (Chandra Shekara, 2007).The present study was conducted to know the profile of agricultural input dealers under four major category of variables i.e. personal, socio-economic, psychological and extension variables in Purba Bardhaman and Hooghly districts of West Bengal.

\section{Materials and Methods}

\section{Study area}

Two districts of West Bengal i.e. Purba Bardhaman and Hooghly were purposively selected for the study. Purba Bardhaman is known as the 'Granary of West Bengal' and Hooghly serves as the main potato belt of West Bengal. Besides cultivation of these two staple crops in West Bengal, both the districts are having good production and productivity in diversified crops such as wheat, jute, vegetables, rape seed and mustard etc. Crops are grown thrice in a year and various cropping systems are followed.

Due to the potentiality of the areas in agricultural production, both the districts are having a large number of agricultural input dealers. Considering these facts and specific reasons, these two districts i.e. Purba Bardhaman and Hooghly districts of West Bengal were purposively selected for the study. Both the districts were having four sub- 
divisions each. One block from each of the sub-divisions from both the districts were selected for the present study. Thus, selecting eight blocks together from two districts.

\section{Selection of the respondents}

From each block, 10 agricultural input dealers, who had undergone DAESI training programme, were selected randomly and thus totalling to a total sample of 80 agricultural input dealers. Data were collected using personal interview method with the help of pre-structured interview schedule. The data collected from the agricultural input dealers under this investigation were scored, classified, tabulated and analysed.

\section{Results and Discussion}

Profile of the agricultural input dealers were studied with respect to four major category of variables: personal, socio-economic, psychological and extension variables.

\section{Personal and socio-economic variables}

\section{Age}

Information in table 1 revealed that majority of the respondents (61.25\%) were middle aged, followed by respondents who are old aged $(25.00 \%)$ and young aged (13.75\%).

\section{Education}

It was found that 31.25 per cent of the respondents had their formal education up to graduation, 28.75 per cent of the respondents had their education up to higher secondary school, followed by respondents having their education up to high school $(22.50 \%)$. A less percentage of the respondents had any sort of technical education (8.75\%), followed by respondents $(5.00 \%)$ who had pursued postgraduation and above and respondents $(3.75 \%)$ who did agricultural graduation.

\section{Annual income}

Majority of the respondents were under medium income group $(62.50 \%)$ followed by respondents under low income group $(20.00 \%)$ and respondents under high income group $(17.50 \%)$.

\section{Location of the enterprise}

Table 1 revealed majority of the enterprises were located in villages $(42.50 \%)$,followed by 27.50 per cent of the enterprises located in block headquarters, 18.75 per cent of the enterprises located in municipality areas and 11.25 per cent of the enterprises located in district headquarters.

\section{Entrepreneurial experience as an agricultural input dealer}

The data in table 1 revealed that 37.50 per cent of the respondents were having entrepreneurial experience of 11-15 years as an agricultural input dealer, 27.50 per cent of the respondents had entrepreneurial experience of 6-10 years as an agricultural input dealer, followed by respondents $(23.75 \%)$ with $1-5$ years and respondents $(11.25 \%)$ with more than 15 years of entrepreneurial experience as an agricultural input dealer.

\section{Types of agricultural inputs sold}

It can be concluded from table 1 that majority of the respondents $(57.50 \%)$ dealt with two types of inputs. 26.25 per cent of the respondents dealt with three type of inputs followed by 16.25 per cent of the respondents dealing with only one type of input.

From table 2, it was found that majority of the input dealers were selling fertilizers $(92.50 \%)$ and pesticides (96.25\%). This is because both Purba Bardhaman and Hooghly districts have rice and potato as their main crop besides jute, 
vegetables etc., which require huge quantity of fertilizers and pesticides. Besides, in both the districts three crops are grown in a year and thus there lies a demand for fertilizers and pesticides all-round the year and hence a less possibility of the enterprise running into a loss.

\section{Psychological variables}

Psychological characteristics of the agricultural input dealers were studied with respect to cosmopoliteness, self-confidence, opinion of trained input dealers on DAESI training, deferred gratification, competition orientation, credit orientation, level of aspiration, empathy and information sharing behaviour.

\section{Cosmopoliteness}

Result in Table 3 shows that 53.75 per cent of the respondents were having medium cosmopoliteness, followed 26.25 per cent of the respondents and 20.00 per cent of the respondents having high and low cosmopoliteness respectively.

\section{Self-confidence}

With respect to self-confidence, it was found from Table 3 that majority of the respondents were having high self-confidence $(45.00 \%)$, 37.50 per cent of the respondents were having medium level of self-confidence, and 17.50 per cent of the respondents were having low level of self-confidence.

Majority of the respondents belonging to the high level of self-confidence testimonies that the respondents had more confidence in them to run the business smoothly as well as providing agro-advisory services to the farmers.

\section{Opinion of trained input dealers on DAESI training}

Findings from the study as presented in Table 3 clearly indicates that majority of the respondents were having average to good opinion $(85.00 \%)$ about DAESI training and only 15.00 per cent of the respondents are having poor opinion about DAESI training.

\section{Deferred gratification}

The results in Table 3 revealed that more than half of the respondents were having medium deferred gratification $(51.25 \%)$ followed by 32.50 per cent of the respondents with high deferred gratification and 16.25 per cent of the respondents having low deferred gratification. Majority of respondents had medium deferred gratification $(51.25 \%)$.

\section{Competition orientation}

The data in Table 3 revealed that 45.00 per cent of the respondents belonged to medium level of competition orientation, whereas 31.25 per cent of the respondents belonged to high level of competition orientation and 23.75 per cent of the respondents belonged to low level of competition orientation.

\section{Credit orientation}

Result in Table 3 showed that most of the respondents $(48.75 \%)$ had high credit orientation followed by 33.75 per cent of the respondents with medium and 17.50 per cent of the respondents with low credit orientation.

This indicates that majority of the agricultural input dealers were depending on credit for running their business. Also, they were having sound knowledge regarding the availability and use of credit. 
Table.1 Distribution of respondents according to personal and socio-economic variables

\begin{tabular}{|c|c|c|c|c|c|}
\hline $\begin{array}{l}\text { Sl. } \\
\text { No. }\end{array}$ & Variables & Mean & $\begin{array}{l}\text { Standard } \\
\text { deviation }\end{array}$ & Frequency & Percentage \\
\hline 1 & $\begin{array}{c}\text { Age } \\
\text { Young (Less than } 35 \text { years) } \\
\text { Middle (35-50 years) } \\
\text { Old (Above } 50 \text { years) }\end{array}$ & & & $\begin{array}{l}11 \\
49 \\
20\end{array}$ & $\begin{array}{l}13.75 \\
61.25 \\
25.00\end{array}$ \\
\hline 2 & $\begin{array}{c}\text { Education } \\
\text { Illiterate } \\
\text { Primary school } \\
\text { High School } \\
\text { Higher secondary school } \\
\text { Graduation } \\
\text { Agricultural graduation } \\
\text { Post-graduation and above } \\
\text { Any other technical course }\end{array}$ & & & $\begin{array}{c}0 \\
0 \\
18 \\
23 \\
25 \\
3 \\
4 \\
7\end{array}$ & $\begin{array}{c}0 \\
0 \\
22.50 \\
28.75 \\
31.25 \\
3.75 \\
5.00 \\
8.75\end{array}$ \\
\hline 3 & $\begin{array}{c}\text { Annual income } \\
\text { Low }(<2.76) \\
\text { Medium }(2.76-4.16) \\
\text { High }(>4.16)\end{array}$ & 3.4625 & 1.404 & $\begin{array}{l}16 \\
50 \\
14\end{array}$ & $\begin{array}{l}20.00 \\
62.50 \\
17.50\end{array}$ \\
\hline 4 & $\begin{array}{l}\text { Location of the enterprise } \\
\text { Village } \\
\text { Block headquarters } \\
\text { Municipality } \\
\text { District headquarter }\end{array}$ & & & $\begin{array}{c}34 \\
22 \\
15 \\
9\end{array}$ & $\begin{array}{l}42.50 \\
27.50 \\
18.75 \\
11.25\end{array}$ \\
\hline 5 & $\begin{array}{c}\text { Entrepreneurial experience as an } \\
\text { agricultural input dealer } \\
1-5 \text { years } \\
6-10 \text { years } \\
11-15 \text { years } \\
>15 \text { years }\end{array}$ & & & $\begin{array}{c}19 \\
22 \\
30 \\
9\end{array}$ & $\begin{array}{l}23.75 \\
27.50 \\
37.50 \\
11.25\end{array}$ \\
\hline 6 & $\begin{array}{c}\text { Types of agricultural inputs sold } \\
\text { One type } \\
\text { Two types } \\
\text { Three types } \\
\text { More than three types }\end{array}$ & & & $\begin{array}{c}13 \\
46 \\
21 \\
0\end{array}$ & $\begin{array}{c}16.25 \\
57.50 \\
26.25 \\
0\end{array}$ \\
\hline
\end{tabular}

Table. 2 Distribution of the respondents according to the types of agricultural inputs sold

\begin{tabular}{|c|c|c|c|}
\hline SI. No. & Agricultural inputs & Frequency & Percentage \\
\hline $\mathbf{1}$ & Seeds & 48 & 60.00 \\
\hline $\mathbf{2}$ & Fertilizers/bio-fertilizers & 74 & 92.50 \\
\hline $\mathbf{3}$ & Pesticides/herbicides/fungicides & 77 & 96.25 \\
\hline $\mathbf{4}$ & Agricultural tools and implements & 11 & 13.75 \\
\hline
\end{tabular}


Table.3 Distribution of respondents according to psychological variables

\begin{tabular}{|c|c|c|c|c|c|}
\hline Sl. No. & Variables & Mean & $\begin{array}{l}\text { Standard } \\
\text { deviation }\end{array}$ & Frequency & Percentage \\
\hline 1 & $\begin{array}{c}\text { Cosmopoliteness } \\
\text { Low }(<12.36) \\
\text { Medium }(12.36-18.28) \\
\text { High }(>18.28)\end{array}$ & 15.32 & 5.91 & $\begin{array}{l}16 \\
43 \\
21\end{array}$ & $\begin{array}{l}20.00 \\
53.75 \\
26.25\end{array}$ \\
\hline 2 & $\begin{array}{c}\text { Self confidence } \\
\text { Low }(<17.40) \\
\text { Medium }(17.40-18.99) \\
\text { High }(>18.99) \\
\end{array}$ & 18.20 & 1.59 & $\begin{array}{l}14 \\
30 \\
36\end{array}$ & $\begin{array}{c}17.50 \\
37.5 \\
45.00\end{array}$ \\
\hline 3 & $\begin{array}{c}\text { Opinion of trained input } \\
\text { dealers on DAESI training } \\
\text { Poor }(<24.66) \\
\text { Average }(24.66-27.01) \\
\text { Good }(>27.01)\end{array}$ & 25.84 & 2.35 & $\begin{array}{l}12 \\
49 \\
19\end{array}$ & $\begin{array}{l}15.00 \\
61.25 \\
23.75\end{array}$ \\
\hline 4 & $\begin{array}{l}\text { Deferred gratification } \\
\text { Low }(<31.98) \\
\text { Medium }(31.98-34.66) \\
\text { High }(>34.66)\end{array}$ & 33.32 & 2.67 & $\begin{array}{l}13 \\
41 \\
26\end{array}$ & $\begin{array}{l}16.25 \\
51.25 \\
32.50\end{array}$ \\
\hline 5 & $\begin{array}{c}\text { Competition orientation } \\
\text { Low }(<19.86) \\
\text { Medium }(19.86-21.66) \\
\text { High }(>21.66)\end{array}$ & 20.76 & 1.80 & $\begin{array}{l}19 \\
36 \\
25\end{array}$ & $\begin{array}{l}23.75 \\
45.00 \\
31.25\end{array}$ \\
\hline 6 & $\begin{array}{c}\text { Credit orientation } \\
\text { Low }(<16.73) \\
\text { Medium }(16.73-18.71) \\
\text { High }(>18.71)\end{array}$ & 17.73 & 1.98 & $\begin{array}{l}14 \\
27 \\
39\end{array}$ & $\begin{array}{l}17.50 \\
33.75 \\
48.75\end{array}$ \\
\hline 7 & $\begin{array}{c}\text { Level of aspiration } \\
\text { Low }(<17.59) \\
\text { Medium }(17.59-21.41) \\
\text { High }(>21.41)\end{array}$ & 19.50 & 3.82 & $\begin{array}{l}24 \\
32 \\
24\end{array}$ & $\begin{array}{l}30.00 \\
40.00 \\
30.00\end{array}$ \\
\hline 8 & $\begin{array}{c}\text { Empathy } \\
\text { Low }(<19.92) \\
\text { Medium }(19.92-21.32) \\
\text { High }(>21.32)\end{array}$ & 20.63 & 1.39 & $\begin{array}{l}13 \\
45 \\
22\end{array}$ & $\begin{array}{l}16.25 \\
56.25 \\
27.50\end{array}$ \\
\hline 9 & $\begin{array}{c}\text { Information sharing } \\
\text { behaviour } \\
\text { Low }(<7.62) \\
\text { Medium }(7.62-9.47) \\
\text { High }(>9.47)\end{array}$ & 8.55 & 1.85 & $\begin{array}{l}15 \\
40 \\
25\end{array}$ & $\begin{array}{l}18.75 \\
50.00 \\
31.25\end{array}$ \\
\hline
\end{tabular}


Table.4 Distribution of respondents according to communication and extension variables

\begin{tabular}{|c|c|c|c|c|c|}
\hline Sl. No. & Variables & Mean & $\begin{array}{l}\text { Standard } \\
\text { deviation }\end{array}$ & Frequency & Percentage \\
\hline 1 & $\begin{array}{l}\text { Extension Contact } \\
\text { Low }(<14.53) \\
\text { Medium }(14.53-18.01) \\
\text { High }(>18.01)\end{array}$ & 16.28 & 3.49 & $\begin{array}{l}15 \\
44 \\
21\end{array}$ & $\begin{array}{l}18.75 \\
55.00 \\
26.25\end{array}$ \\
\hline 2 & $\begin{array}{c}\text { Extension participation } \\
\text { Low }(<10.82) \\
\text { Medium }(10.82-12.92) \\
\text { High }(>12.92)\end{array}$ & 11.87 & 2.09 & $\begin{array}{l}14 \\
43 \\
23\end{array}$ & $\begin{array}{l}17.50 \\
53.75 \\
28.75\end{array}$ \\
\hline 3 & $\begin{array}{c}\text { Social participation } \\
\text { Low }(<10.70) \\
\text { Medium }(10.70-12.36) \\
\text { High }(>12.36)\end{array}$ & 11.54 & 1.66 & $\begin{array}{l}23 \\
31 \\
26\end{array}$ & $\begin{array}{l}28.75 \\
38.75 \\
32.50\end{array}$ \\
\hline 4 & $\begin{array}{c}\text { Mass media participation } \\
\operatorname{Low}(<24.88) \\
\text { Medium }(24.88-28.24) \\
\operatorname{High}(>28.24)\end{array}$ & 26.56 & 3.36 & $\begin{array}{l}14 \\
42 \\
24\end{array}$ & $\begin{array}{l}17.50 \\
52.50 \\
30.00\end{array}$ \\
\hline 5 & $\begin{array}{c}\text { Mode of advertisement } \\
\text { One mode } \\
\text { Two modes } \\
\text { Three modes } \\
\text { More than three modes }\end{array}$ & & & $\begin{array}{c}49 \\
14 \\
17 \\
0\end{array}$ & $\begin{array}{c}61.25 \\
17.50 \\
21.25 \\
0\end{array}$ \\
\hline 6 & $\begin{array}{c}\text { Training received } \\
\text { Low }(<5) \\
\text { Medium }(5-10) \\
\text { High }(>10)\end{array}$ & & & $\begin{array}{c}17 \\
54 \\
9\end{array}$ & $\begin{array}{l}21.25 \\
67.50 \\
11.25\end{array}$ \\
\hline
\end{tabular}

Table.5 Distribution of respondents according to the area of training received by them

\begin{tabular}{|r|c|c|c|c|}
\hline \multicolumn{2}{|c}{} & \multicolumn{3}{c|}{$(\mathrm{n}=80)$} \\
\hline SI. & Training received & Respondents & Percentage & Rank \\
No. & Agri-business management & 38 & 47.50 & IX \\
\hline $\mathbf{1}$ & Post-harvest management & 52 & 65.00 & VI \\
\hline $\mathbf{2}$ & Communication skills & 23 & 28.75 & XIII \\
\hline $\mathbf{3}$ & Crop production techniques & 63 & 78.75 & IV \\
\hline $\mathbf{4}$ & Diagnostic skills & 47 & 83.75 & II \\
\hline $\mathbf{5}$ & Integrated nutrient management & 29 & 56.25 & VIII \\
\hline $\mathbf{6}$ & Computer skills & 32 & 46.25 & XII \\
\hline $\mathbf{7}$ & 64 & 80.00 & X \\
\hline $\mathbf{8}$ & Soil sampling, analysis and interpretation of results & 68 & 85.00 & III \\
\hline $\mathbf{9}$ & Sustainable agricultural management & 31 & 38.75 & I \\
\hline $\mathbf{1 0}$ & Integrated pest management & 47 & 58.75 & VII \\
\hline $\mathbf{1 1}$ & Documentation skills & 57 & 71.25 & V \\
\hline $\mathbf{1 2}$ & Legal aspects: insecticide and pesticide act & & & \\
\hline $\mathbf{1 3}$ & Storage of agricultural inputs & & & \\
\hline
\end{tabular}


Fig.1 Distribution of respondents according to the mode of advertisement

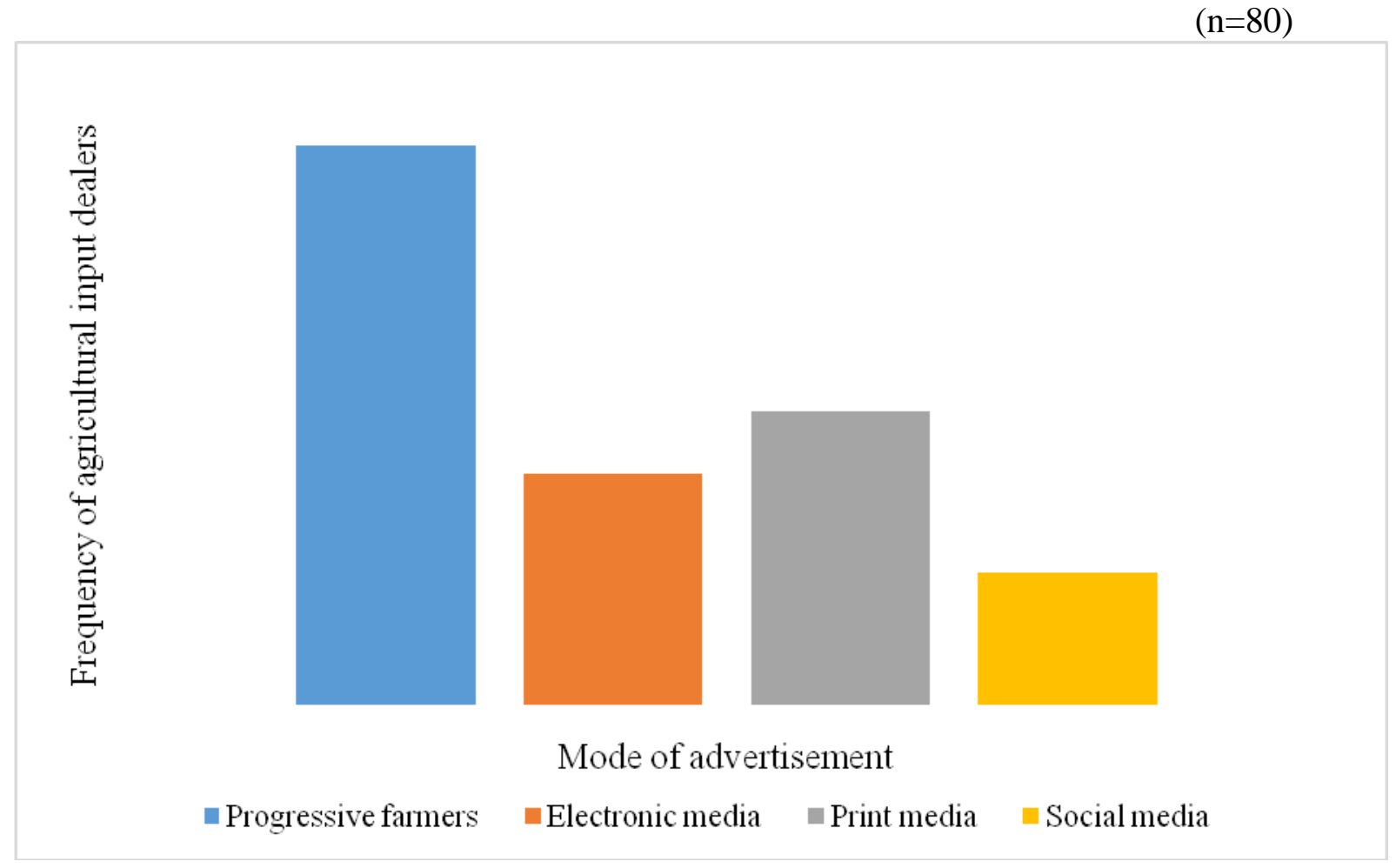

\section{Level of aspiration}

Results in Table 3 showed that as high as 40.00 per cent of the respondents had medium level of aspiration. Equal number of the respondents $(30.00 \%)$ was categorized under low and high level of aspiration.

\section{Empathy}

The result in Table 3 showed that 56.25 per cent of the respondents had medium empathetic attitude towards others. Whereas, 27.50 per cent and 16.25 per cent of the respondents had high and low empathy respectively. This might be due to main consideration towards running of the business as well as effective role performance in agroadvisory services towards the farmers.

\section{Information sharing behaviour}

The result in Table 3 revealed that half of the respondents belong to the medium level of information sharing behaviour (50.00\%) followed by 31.25 per cent of the respondents belonging to level of high information sharing behaviour and 18.75 per cent of the respondents belonging to low level of information sharing behaviour.

\section{Extension variables}

Communication and extension characters of the agricultural input dealers were studied with respect to extension contact, extension participation, social participation, mass media participation, mode of advertisement and training received.

\section{Extension contact}

Result in Table 4 stated that majority of respondents $(55.00 \%)$ had medium extension contact followed by respondents $(26.25 \%)$ with high level of extension contact and respondents $(18.75 \%)$ with low level of extension contact. 


\section{Extension participation}

The data in Table 4 revealed that categorization of respondents with respect to extension participation is similar to categorization of respondents with respect to extension contact. Majority of the respondents $(53.75 \%)$ had medium level of extension participation. 28.75 per cent of the respondents had high level of extension participation and 17.50 percent of the respondents had low level of extension participation.

\section{Social Participation}

It was found in Table 4 that majority of the respondents $(38.75 \%)$ had medium social participation followed by 32.50 per cent of the respondents with high social participation and 28.75 per cent of the respondents with low social participation.

\section{Mass media participation}

The data in Table 4 showed that more than half of the respondents $(52.50 \%)$ had medium mass media participation, followed by 30.00 per cent of the respondents with high mass media participation and 17.50 per cent of the respondents with low mass media participation.

\section{Mode of advertisement}

The result in Table 4 revealed that majority of the respondents were using a single mode of advertisement $(61.25 \%)$ for their enterprise, followed by 21.25 and 17.50 per cent of the respondents who are using three modes and two modes of advertisement for their enterprise respectively.

From Figure 1, it could be said that all the agricultural input dealers $(100.00 \%)$ understudy advertised their products through progressive farmers. Other modes of advertisement used are print media (52.50\%), electronic media $(41.25 \%)$ and social media (23.75\%).Progressive farmers had always been the most direct and trustworthy mode of the advertisements for the agricultural input dealers. The information is diffused in the farming society from these progressive farmers, who not only possess high credibility butal so acts as opinion leaders for the fellow farmers.

\section{Training received}

It can be concluded from Table 4 that 88.75 per cent of the respondents had undergone up to 0 to 10 trainings. Only 11.25 per cent of the respondents had undergone more than 10 trainings.

Findings in Table 5 revealed that majority of the respondents had received training on integrated pest management $(85.00 \%)$ followed by diagnostic skills $(83.75 \%)$ and sustainable agricultural management (80.00 $\%)$. Other areas of training agricultural input dealers were exposed to were crop production techniques $(78.75 \%)$, storage of agricultural inputs $(71.25 \%)$, post-harvest management (65.00 \%), legal aspect: insecticides and pesticides act $(58.75 \%)$, integrated nutrient management (56.25 \%), agri-business management $(47.50 \%)$, soil sampling, analysis and interpretation of results (40.00 $\%)$, documentation skills (38.75\%), computer skills $(36.25 \%)$ and communication skills $(28.75 \%)$.

It can be concluded from the study that majority of the agricultural input dealers were of middle aged (between 35-50 years). Majority of the input dealers were from village side, had formal education level upto graduation, and had medium annual income with an entrepreneurial experience between 11-15 years. Maximum agricultural input dealers had medium cosmopoliteness, high 
self-confidence, medium deferred gratification, medium competition orientation, high credit orientation, medium level of aspiration, medium empathy, medium information sharing behaviour, medium extension contact, medium extension participation, medium social participation, medium mass media participation, had received medium number of trainings (5-10). The findings also revealed that majority of the agricultural input dealers were dealing with two types of agricultural inputs, and had a single mode of advertisement. Thus, a detailed study on profile characteristics of the agricultural input dealers is very crucial for the policy makers before designing any strategies to enhance the entrepreneurial behaviour as well as the role performance of the agricultural input dealers.

\section{Acknowledgement}

We express our sincere thanks to University of Agricultural Sciences, Bangalore for giving this opportunity to carry on this research as well as guiding this research. We are thankful to Indian Council of Agricultural Research for funding through National Talent Scholarship.
We also acknowledge officials from KVK, Bardhaman; ATC, Purba Bardhaman;DDA (admn.), Purba Bardhaman; KVK, Hooghly; DDA (admn.), Hooghly and SAMETI, West Bengal for their cordial cooperation in collection of data for my research.

\section{References}

ANONYMOUS, 2020, www.statista.com

Khose, 2004. Zonal Conference, RABl-200405, Fertilizer Marketing News.35: 7-8

Nandi, R. and Nedumaran, S., 2019. Agricultural Extension System in India: A Meta-analysis. Res. Jr. of Agril. Sci. 10(3):473-479

Padmanabhan, N. R., 1999. Brand and dealer loyalty of farmers to pesticides in Tamilnadu. Indian J. Agric. Marketing.13(1): 24-29

Press Information Bureau. (2020, September 21). Union Minister of Agriculture and Farmers Welfare Shri Narendra Singh Tomar kick starts National Rabi Campaign 2020 for Aatmanirbhar Kheti [Press Release]. Retrieved from https://pib.gov.in/PressReleseDetailm. aspx?PRID=1657225

\section{How to cite this article:}

Amitava Panja, N. S. Shivalinge Gowda, D. V. Kusumalatha and Mamathalakshmi, N. 2021. Profile Characteristics of Agricultural Input Dealers in West Bengal. Int.J.Curr.Microbiol.App.Sci. 10(02): 2100-2109. doi: https://doi.org/10.20546/ijcmas.2021.1002.250 